Science, Technology and Development 34 (4): 270-273, 2015

ISSN 0254-6418 / DOI: 10.3923/std.2015.270.273

(C) 2015 Pakistan Council for Science and Technology

\title{
Impact of Climate Change on Livestock Composition in Pothwar Region, Pakistan
}

\author{
Sobia Naheed, Irum Raza, Tariq Hassan, Muhammad Zubair Anwar and Anum Fatima \\ Social Sciences Research Institute, National Agricultural Research Centre, Pakistan
}

\begin{abstract}
A research study was planned to assess the impact of climate change on livestock composition during 2014, in Pothwar region of Pakistan. Data regarding this experiment were collected through questionnaire by queering 61 respondents. Paired t-test was used to check the difference between livestock composition in present and before 10 years. The results showed that paired sample t-test of livestock in which difference values for mean, standard deviation and standard error of mean for cattle are $-0.525,1.840$ and 0.236 , respectively, having T-value, equal to 2.23 and p-value, equal to 0.03 , which is significant at $1 \%$. Similarly, buffalo group indicated difference in values of mean, standard deviation and standard error of mean $-0.607,2.193$ and 0.281 , respectively. The paired T-statistic also shows significant difference with t-value, p-value less than 0.05 , which show significance level. Likewise goat group pointed out difference values of mean, standard deviation and standard error of mean are -0.836, 2.544 and 0.326 respectively that comprises p-value equal to 0.01 , which is significant at $1 \%$.
\end{abstract}

Key words: Livestock, climate change, composition, paired t-test, standard deviation, pothwar

\section{INTRODUCTION}

Climate change refers to any change in climate over the time, whether it is due to natural variability or as a result of human activity. The effects of gradual climate changes and extreme weather events in the recent past resulted crop failures, fishery collapses and livestock deaths that already caused in heavy economic losses and undermine food security, further these are likely to become more severe as global warming continues (Challinor et al., 2003).

Although, livestock is the backbone of agriculture and this sub-sector constitutes an important source of food and means of nutrition for millions of households in Pakistan and almost 11.9\% share, in the GDP of Pakistan that depends on the livestock. It is a major source of livelihood for many rural and middle grade farmers. It is also reported that only $2 \%$ of total milk production was utilised by UHT industry (Iqbal et al., 1999). During 2012-13, there was 55.4\% contribution of livestock in the agriculture sector. Current livestock-population of the country includes 33.7 million buffaloes, 38.3 million cattle, 28.8 million sheep, 29.9 million goats and 1 million camels (GOP., 2013). Livestock has appeared as a subsistence sector, dominated by small holders to fulfill their needs of milk, food and cash income on daily basis. In the rural areas, livestock is considered as a more secure source of income for small farmers and landless poor people ( Husnain and Usmani, 2006).
Livestock sector has an important role towards the development of rural economy and its importance may well be recognized from the fact that 35-40 million rural population is dependent on livestock (Anonymous, 2010). Livestock, though being a neglected sector, plays a vital role in our national economy, as it provides draught power, high biological value of animal proteins and its by-products (hides, skin, wool, mohair, bones and manure) (Sarwar et al., 2002). On the other hand, rapidly increasing demands for livestock products further intensify the enormously triggered pressure on these rangelands (GOP., 2013).

In the presence of all these factors, the development of livestock sector is less as compared to development in agriculture sector that is $2.8 \%$, as compared to agriculture's growth rate (5.5\%) (Anonymous, 2000), whereas, during 2010-2011, livestock growth was $3.7 \%$ as compared to agriculture growth, which is $1.2 \%$. Despite start in artificial insemination techniques in Pakistan (in late 50s), the development of these techniques is slow. Only $7 \%$ of cattle and 5\% of buffaloes are bred by this technique. Economic traits have a wide variation and the genetic control is moderate for production traits but very low for reproduction traits. Inbreeding is inimical to genetic diversity and has been reported to deteriorate productivity. Efforts to improve productivity of the species are needed along with sustainable utilization of existing resources (Khan et al., 2007). 
Sci. Technol. Dev., 34 (4): 270-273, 2015

Keeping in view the importance of climate change impact on livestock, this research study was planned to assess the difference between number of livestock at present and 10 years before due to climate change in Pothwar region in Pakistan.

\section{METHODOLOGY}

This study is based on a primary data and was carried out in 2014. A questionnaire was designed for collecting data from selected villages of Pothwar region. This area was selected as study area purposively because this is rain-fed area and such areas are fragile and are directly affected by climate change. A sample of 61 respondents, having livestock, were interviewed. The purpose of conducting the survey was to find the difference between the impact of climate change on livestock before and after 10 years.

Statistical analysis: For this purpose statistical technique named as paired t-test was applied on data, using MINITAB. (2007). There are many situations when we want to compare two treatments and where the observations are obtained in the form of pairs. These pairs consist of the measurement before and after the treatments. The paired t-test is calculated to take into account the fact that pairs of subjects (one from each condition) go together. It is based on the differences between the values of each pair-that is one subtracted from the other. In the formula for a paired t-test, this difference is notated as $d$.

The test statistic is calculated as:

$$
\mathrm{t}=\frac{\overline{\mathrm{d}}}{\sqrt{\mathrm{s}^{2} / \mathrm{n}}}
$$

where, $\mathrm{d}$ bar is the mean difference, $\mathrm{s}^{2}$ is the sample variance, $n$ is the sample size and $t$ is a student $t$ quintile with n-1 degrees of freedom.

\section{RESULTS AND DISCUSSION}

The results of paired t-test are summarized in Table 1. On an average the present livestock composition for cattle is less than it was 10 years before because the mean value before 10 years for cattle (2.180) is greater than present mean value for cattle (1.65). On an average people had more buffaloes before 10 years than present. The number of sheep has increased in the present year as its mean value (6.43) is greater than it was before 10 years
Table 1: Paired samples statistics of livestock composition

\begin{tabular}{lccc}
\hline $\begin{array}{l}\text { Livestock composition } \\
\text { (Present, before) }\end{array}$ & Mean & $\begin{array}{l}\text { Standard } \\
\text { deviation }\end{array}$ & $\begin{array}{c}\text { Standard e Error } \\
\text { of Mean (SEM) }\end{array}$ \\
\hline $\begin{array}{l}\text { Number of cattle } \\
\text { Present }\end{array}$ & 1.65 & 2.17 & 0.28 \\
$\begin{array}{l}\text { Before } 10 \text { years } \\
\text { Number of buffaloes }\end{array}$ & 2.18 & 2.92 & 0.38 \\
$\begin{array}{l}\text { Present } \\
\text { Before } 10 \text { years }\end{array}$ & 1.03 & 1.24 & 0.16 \\
$\begin{array}{l}\text { Number of sheep } \\
\text { Present }\end{array}$ & 1.64 & 2.12 & 0.27 \\
$\begin{array}{l}\text { Before } 10 \text { years } \\
\text { Number of goats }\end{array}$ & 6.43 & 5.10 & 1.93 \\
$\begin{array}{l}\text { Present } \\
\text { Before } 10 \text { years }\end{array}$ & 2.02 & 7.30 & 0.93 \\
\hline SourC Surve dat & 2.90 & 3.91 & 0.50 \\
\hline
\end{tabular}

Source: Survey data author's own calculation, 2014

Table 2: Paired sample t-test of livestock composition

\begin{tabular}{lccccc}
\hline Difference* & Mean & St. Dev & SE Mean & T-value & p-value \\
\hline Cattle & -0.525 & 1.840 & 0.236 & -2.23 & 0.030 \\
Buffaloes & -0.607 & 2.193 & 0.281 & -2.16 & 0.035 \\
Sheep & 2.41 & 13.09 & 1.68 & 1.68 & 0.156 \\
Goats & -0.836 & 2.544 & 0.326 & -2.57 & 0.013 \\
\hline
\end{tabular}

*Paired t-test for livestock composition (present)-paired t-test for livestock composition (10 year before), 2014

(4.02). On the other hand, the number of goats has decreased because the mean value (2.06) in the present year is less than it was before 10 years (2.90). The values of SEM show greater variability among the groups. Within the group, variation is also found from the values of SEM, which is depicted in Table 1.

The results of paired t-test showed difference values of mean, standard deviation and SEM for cattle are-0.525, 1.840 and 0.236, respectively (Table 2). Paired t-test values for cattle, buffaloes and goats, were significant at $5 \%$ alpha. However, the paired t-test value for sheep was non-significant as the p-value is greater than 0.05 . In various studies, different examples of paired t-test have been used and they present similar results (Amrouk et al., 2013; DeCoster, 2006; Dunlop et al., 1996; Moore and McCabe, 2003). Coulter et al. (2010) have used paired t-test for vegetation response to seasonality of prescribed fire and post fire seeding following mechanical fuel-reduction treatments. For example, the data were analyzed, using t-tests by comparing 2005 burn plots versus 2007 burn plots and 2007 burn plots versus 2007 unburned plots, resulting in two pairwise comparisons. Therefore, the adjustment was applied by dividing the threshold $\mathrm{P}$ value by the number of comparisons (two) conducted by Elzinga et al. (1998). Subsequently, test 24 results were only considered significant if they fell below p $=0.05$ as in Elzinga et al. (1998).

The results of percent change in livestock composition in (Fig. 1) prove that percent change in 


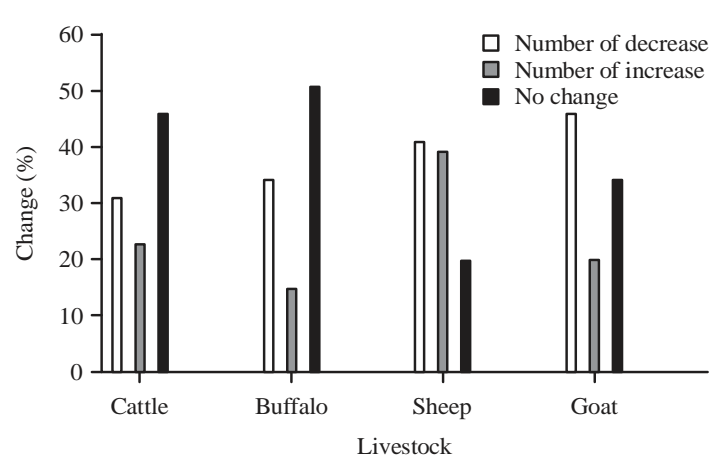

Fig. 1:Percent change in livestock composition present and before 10 years (2014)

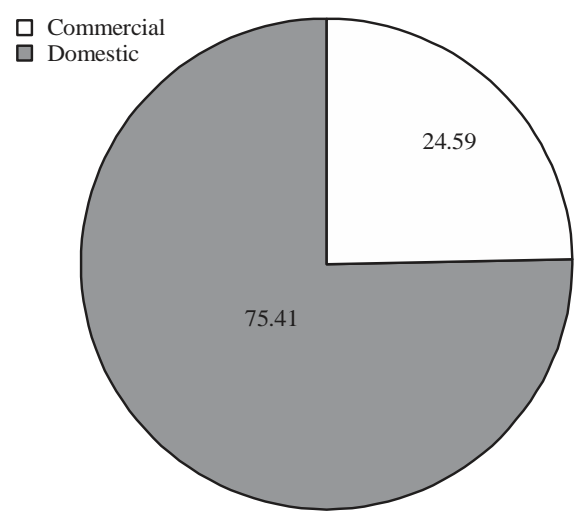

Fig. 2: Purpose for keeping Livestock

present and before 10 years due to climate change in which number of decreases in 10 years for cattle, buffalo, sheep and goat, are 31.15, 34.43, 40.98 and 45.90, respectively. Similarly percent change in number of increases for cattle, buffaloes, sheep and goats are 22.95, $14.75,39.34$ and 19.67, respectively as well as 45.90 , 50.82, 19.67 and $34.43 \%$ no change for cattle, buffaloes, sheep and goats, respectively.

It depicts that percentage for keeping livestock composition in which $24.59 \%$ respondents were for commercial use and $75.41 \%$ for domestic use (Fig. 2).

\section{CONCLUSION}

Paired t-test technique is useful for finding the difference between two variables within a group or among the groups. The results of paired t-test revealed variation in livestock composition of farmers before and after 10 year. This technique, no doubt, is necessary but is not sufficient alone. The technocentric approach should be complemented by considering the social concerns as well. Doing so would help in building the ownership of the campaign to counter the impact of climate change. A policy needs to be devised by taking into consideration the food and energy security of the country. It should be done in a consultative manner in which all the relevant stakeholders are taken on board.

\section{REFERENCES}

Amrouk, E.M., N. Poole, N. Mudungwe and E. Muzvondiwa, 2013. The impact of commodity development projects on smallholders' market access in developing countries. Case study of FAO/CFE Projects, FAO Commodity and Trade Policy Research working paper No. 35. http://www.fao.org/ docrep/017/aq290e/aq290e.pdf.

Anonymous, 2000. Economic survey of Pakistan, 1999-2000. Government of Pakistan, Finance division, Economic Advisor Wing, Islamabad.

Anonymous, 2010. Pakistan economic survey 2009-2010. Economic Advisor's Wing, Finance Division, Government of Pakistan, Islamabad, Pakistan.

Challinor, A.J., J.M. Slingo, T.R. Wheeler, P.Q. Craufurd and D.I.F. Grimes, 2003. Toward a combined seasonal weather and crop productivity forecasting system: Determination of the working spatial scale. J. Applied Meteorol., 42: 175-192.

Coulter, C.T., D. Southworth and P.E. Hostenm, 2010. Prescribed fire and post-fire seeding in brush masticated oak-chaparral: Consequences for native and non-native plants. Fire Ecol., 6: 60-75.

DeCoster, J., 2006. Testing group differences using T-tests, ANOVA, and nonparametric measures. Department of Psychology, University of Alabama 348 Gordon Palmer Hall. http://www.stat-help.com/ ANOVA\%202006-01-11.pdf

Dunlop, W.P., J.M. Cortina, J.B. Vaslow and M.J. Burke, 1996. Meta-analysis of experiments with matched groups or repeated measures designs. Psychol. Meth., 1: $170-177$.

Elzinga, C.L., D.W. Salzer and J.W. Willoughby, 1998. Measuring and Monitoring Plant Populations. CreateSpace Independent Publishing Platform, Washington, United States, pp: 351-353.

GOP., 2013. Pakistan economic survey 2013-2014. Finance Division, Economic Advisors Wing, Islamabad, Pakistan.

Husnain, H.U. and R.H. Usmani, 2006. Livestock of Pakistan. 1st Edn., Livestock Foundation, Islamabad, Pakistan.

Iqbal, M., M. Ahmad and W.A. Jehangir, 1999. An assessment of livestock production potential in Pakistan: Implications for livestock sector policy [with comments]. Pak. Dev. Rev., 38: 615-628. 
Khan, M.S., N. Ahmad and M.A. Khan, 2007. Genetic resources and diversity in dairy buffaloes of Pakistan. Pak. Vet. J., 27: 201-207.

MINITAB., 2007. Statistical Data Analysis Software. Version 15, Minitab Software, Inc., Cary, NC., USA.
Moore, D.S. and G.P. McCabe, 2003. Introduction to the Practice of Statistics. 4th Edn., Freeman, New York. Sarwar, M., M.A. Khan and Z. Iqbal, 2002. Feed resources for livestock in Pakistan. Int. J. Agric. Biol., 4: 186-192. 